\title{
Effects of Saline Water on Shoot and Nutrient Accumulation of Four Wheat Cultivars
}

\author{
Mohammed Q. Khursheed \\ Department of Biology/College of Education/ University of Salahaddin - Erbil \\ E-mail: dmohamad1677@gmail.com
}

(Received 20/1/2014 ; Accepted 7 / 4/2014)

\begin{abstract}
The effect of salinity $\left(0,4,8\right.$ or $\left.12 \mathrm{dSm}^{-1}\right)$ induced by $\mathrm{NaCl}$ in irrigated water was studied on the shoots of wheat cultivars. After 80 days from sowing, fresh and dry weight of shoot and shoot content of Ntot, $\mathrm{P}, \mathrm{K}, \mathrm{Ca}, \mathrm{Mg}$ and $\mathrm{Cu}$ were significantly decreased as salinity level increased, whereas $\mathrm{Na}, \mathrm{Cl}, \mathrm{Mn}$ and $\mathrm{Zn}$ were increased in the shoots of wheat. The highest fresh and shoot dry weight was recorded with Abo-Graib followed by Sham 4 in which both was significantly higher as compared to Rizgary and Semeto. The concentration of Ntot, P, K, Ca, Mg, Na, Cl and Zn showed that there were significant differences among the cultivars. The highest content of Ntot, $\mathrm{P}, \mathrm{K}, \mathrm{Ca}$ and $\mathrm{Mg}$ were found in Abo-Graib and Sham 4 and the lowest concentration in Semeto and Rizgary, and opposite was true with $\mathrm{Na}, \mathrm{Cl}$ and $\mathrm{Zn}$. Indeed, Abo-Graib and Sham 4 cultivar showed significant higher $\mathrm{K} / \mathrm{Na}$ than Semeto and Rizgary. However, non-significant differences were noticed between Semeto and Rizgary cultivars as well as between Abo-Graib and Sham 4 with regarding to the content of studied nutrients. The results shows that Abo-Graib and Sham 4 cultivars are moderately salt-tolerant compare to the other sensitive salt tolerant Rizgary and Semeto cultivars.
\end{abstract}

Keywords: Salinity, Wheat, Abo-Graib, Rizgary, Semeto, Sham 4, K/Na

\section{تأثثر ملوحة الماء في النمو الخضري وتجمع المغذيات لأربعة أصناف من الحنطة}

\section{الملخص}

درس تاثير الملوحة عن طريق اضافة NaCl الى مـاء الري بمستويات صفر و 4 و 8 و 12 ديسيسيمنز/م في الندو

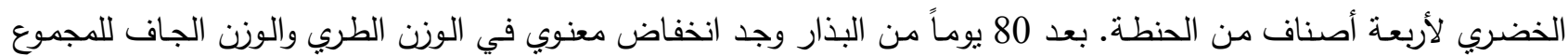
الخضري للنبات ونقص محتواها من النيتروجين والفسفور والبوتاسيوم والكالسيوم والدغنيسيوم والنحاس مع ازدياد مستوى الملوحة،

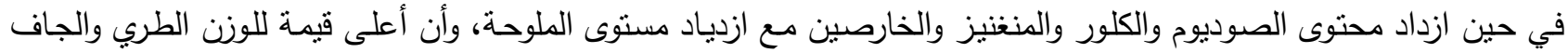
للمجموع الخضري سجلت لنبات صنف ابي غريب ويليه شام 4، وتفوق الصنفان معنوياً على الصنفين رزكاري وسميتو ـ واختلفت الاصـناف فيمـا بينهـا معنويـا مـن حيث نركيز النيتـروجين والفسـفور والبوتاسـيوم والكالسـيوم والمغنيسـيوم و الصـوديوم والكلـور

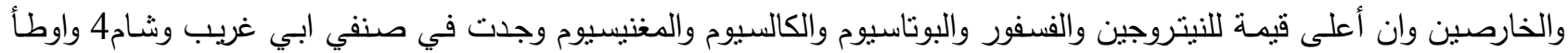

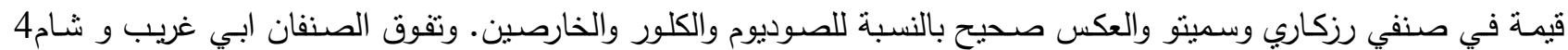
معنويا على صنفي رزكاري وسميتو من حيث نسبة Na/K. ولوحظت اختلافات غير معنوية بين صنف رزكاري وصنف سمينو

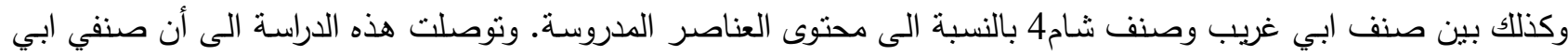
غريب وشام4 منوسطة في درجة تحملها للملوحة مقارنة بصنفي رزكاري وسميتو والتي كانت حساسة للملوحة. 


\section{INTRODUCTION}

Wheat (Triticum aestivum L.) is considered as the major cereal crop in the world in respect of the cultivated area and total production, it cultivated over a wide range of environments because of wide adaptation to diverse environmental conditions. It is a sensitive to moderately salt-tolerant crop (Saboora and Kiarostami, 2006). The earliest written account of salt lands dates back to 2400 $\mathrm{BC}$ and was recorded in the Tigris-Euphrates alluvial plains of Iraq (Russel et al., 1965). Mediterranean regions are currently experiencing increasing salt stress problems resulting from seawater intrusion into aquifers and irrigation with brackish water (Rana and Katerji, 2000). Saline soil can be defined as soil having an electrical conductivity of solution extracted from the watersaturated soil paste ECe of $4 \mathrm{dS} \mathrm{m}^{-1} \approx 40 \mathrm{mM} \mathrm{NaCl}$ or more (Chinnusamy et al., 2005). Salinity is one of the most important abiotic stress and limiting factor for worldwide plant production. Up to $20 \%$ of the irrigated arable land in arid and semiarid regions is already salt affected and is still expanding (Muhling and Lauchli, 2003). The harmful effects of salt on plants are the consequence of both a water deficit that results from the relatively high solute concentrations in the soil as well as a stress specific to $\mathrm{Cl}$ and $\mathrm{Na}$, resulting in a wide variety of physiological and biochemical changes that inhibit plant growth and development (Chinnusamy et al., 2005; Shaddad et al., 2005). Salinity can inhibit plant growth by a range of mechanisms; including low external water potential, ion toxicity and interference with the uptake of nutrients, particulary $\mathrm{K}$, the uptake of water, growth limiting nutrients (such as $\mathrm{P}, \mathrm{Fe}$ or $\mathrm{Zn}$ ) and the growth of soil microorganisms such as mycorrhizal fungi can be inhibited. Leaves are more sensitive than roots to $\mathrm{Na}$ because $\mathrm{Na}$ and $\mathrm{Cl}$ accumulate to higher levels in shoots than in roots (Tester and Davenport, 2003). The degree to which salinity affect growth depends on the plant genotype and environmental conditions (Poustini and Siosemardeh, 2004) and the time scale over which specific damage is manifested depends on the rate of accumulation of $\mathrm{Na}$ in leaves, and on the effectiveness of $\mathrm{Na}$ compartmentation within leaf tissues and cells (Bohnert, 2007).

The objective of the present research is to investigate the effects of saline irrigation water representing by sodium chloride solutions graduated in concentration on shoot biomass, shoot nutrient concentrations, uptake and balance in four wheat cultivars and to assign the most tolerant cultivars.

\section{MATERIALS AND METHODS}

Pot experiment was carried out at the greenhouse of Biology department, College of Education, University of Salahaddin during the period from December 20, 2011 to March 10, 2012. Seeds of wheat cultivars including Rizgary, Abo-Graib, Sham-4 and Semeto were obtained from the Agricultural Research Center of Erbil. The first three cultivars are bread wheat and the fourth one is durum wheat. Germination tests before sowing were performed in petri dishes on two layer of filter paper moistened with water. Forty seeds where placed on each petri dish. Germination percentage was measured at $12 \mathrm{~h}$ intervals and continued until fixed state. Germination percentages were \%87, 90\%, \%84 and \% 86 for Semeto, Rizgary, Abo-Graib and Sham-4, respectively. $8 \mathrm{~kg}$ soil was put in plastic pots. Some chemical and physical properties of the soil were analyzed using different methods as described by (Ryan et al., 2001) were shown in Table (1).

Seven wheat grains were sown in each pot; two week after seed germination the seedling were thinned to two per pot. All pots received 1.0g P/kg soil (as Ca-superphosphate, $15.5 \% \mathrm{P}_{2} \mathrm{O}_{5}$ ), $1.5 \mathrm{~g}$ $\mathrm{N} / \mathrm{kg}$ soil (as $\mathrm{NH}_{4} \mathrm{NO}_{3}, 33.5 \% \mathrm{~N}$ ) and $1.0 \mathrm{~g} \mathrm{~K} / \mathrm{kg}$ soil $\left(\right.$ as $\mathrm{K}_{2} \mathrm{SO}_{4}, 48.5 \% \mathrm{~K}_{2} \mathrm{O}$ ). Application of $\mathrm{K}$ and $\mathrm{P}$ fertilizer nutrients was done in a form of water solution added in the first irrigation. Nitrogen fertilizer was added in three equal doses, at 1 st, $3 \mathrm{rd}$ and within the 5 th irrigation, respectively. Five solutions of electrical conductivity (EC) accounted for 0 (only tap water: control), 4,8 or $12 \mathrm{dSm}^{-1}$ were prepared based on methods by Rhoades et al., (1992). Irrigation with chloride solutions started at 30days after sowing with 4 days intervals to maintain the soil moisture content at the field capacity of the used soils during plant growth. Average temperature in the greenhouse varied from 
11 to $22{ }^{\circ} \mathrm{C}$ during night and day, respectively. Relative humidity in greenhouse ranged from $40 \%$ to $75 \%$ at day and night, respectively.

The plant shoots were collected after 80 days (at stem elongation stage) from sowing, washed with tap water then by distilled water, dried in an oven at $70^{\circ} \mathrm{C}$ for $48 \mathrm{hrs}$ and the fresh and dry weights were recorded. Water percent obtained by subtracting shoot dry weight from shoot fresh weight multiplying by 100 . Sub-samples of plants were ground using stainless steal mill. Powdered dried shoots sample of $0.3 \mathrm{~g}$ were taken in digestion tubes, and digested by adding $10 \mathrm{ml}$ of concentrated sulfuric acid and $10 \mathrm{ml}$ of $\mathrm{H}_{2} \mathrm{O}_{2}$ with heating for digestion as described by Ryan et al., (2001). Total nitrogen (Ntot) was estimated from the digested plant by Kjeldahl method (Ryan et al., 2001) according to the equation: $\% \mathrm{Ntot}=(\mathrm{T}-\mathrm{B}) \times \mathrm{Nx} 1.4 / \mathrm{g}$ sample) where, $\mathrm{T}=\mathrm{ml}$ of sample titrated, $\mathrm{B}=\mathrm{ml}$ of blank titrated and $\mathrm{N}=$ acid normality. Sodium, $\mathrm{K}$ and $\mathrm{Ca}$ were estimated by flame emission photometer technique as adopted by (Temminghoff and Houba, 2004). Chloride was estimated according to Mohr method which was described by Pandey et al., (2000). Mg, Mn, $\mathrm{Cu}$ and $\mathrm{Zn}$ content were determined simultaneously from the plant digestion by using atomic absorbance spectrophotometer as described by Hanlon (1992). The experiment was factorial laid in randomized design, included (16) treatments with 3 replicates. The statistical analyses were performed using SPSS for windows, version 18 (Levesque, 2007). Data were subjected to statistical analysis of variance (ANOVA). When ANOVA showed a significant $(\mathrm{P}<0.05)$ effect, the least significant differences (L.S.D) where used to compare treatments.

Table 1: Soil chemical and physical characteristics

\begin{tabular}{|c|c|c|c|c|}
\hline \multicolumn{2}{|l|}{ Properties } & Values & Properties & Values \\
\hline \multirow{3}{*}{$\begin{array}{l}\text { Particle Size } \\
\text { Distribution }\left(\mathrm{g} \mathrm{kg}^{-1}\right)\end{array}$} & Sand & 157.5 & Total- $\mathrm{N}\left(\mathrm{g} \mathrm{kg}^{-1}\right)$ & 7.74 \\
\hline & Silt & 276.1 & Available - P(ppm) & 3.49 \\
\hline & Clay & 566.4 & Soluble - K(ppm) & 170.67 \\
\hline \multicolumn{2}{|l|}{ Soil Texture } & Clay Loam & Exchangeable -K (meq/L) & 2.41 \\
\hline \multicolumn{2}{|c|}{ Organic matter $\left(\mathrm{g} \mathrm{kg}^{-1}\right)$} & 2.8 & Exchangeable -Ca (meq/L) & 2.69 \\
\hline \multicolumn{2}{|c|}{ Lime $\left(\mathrm{g} \mathrm{kg}^{-1}\right)$} & 301.4 & Exchangeable $-\mathrm{Mg}(\mathrm{meq} / \mathrm{L})$ & 2.03 \\
\hline \multicolumn{2}{|l|}{$\mathrm{EC}\left(\mathrm{dsm}^{-1}\right.$ at $\left.25^{\circ} \mathrm{C}\right)$} & 0.31 & Exchangeable -Na (meq/L) & 0.74 \\
\hline \multicolumn{2}{|c|}{$\mathrm{pH}$} & 8.20 & Available - $\mathrm{Cu}(\mathrm{ppm})$ & 2.43 \\
\hline \multicolumn{2}{|c|}{ Water Content at field capacity $\left(\mathrm{g} \mathrm{kg}^{-1}\right)$} & 26.95 & Available - Mn(ppm) & 2.12 \\
\hline \multicolumn{2}{|c|}{ Soluble Chloride $\left(\mathrm{mg} \mathrm{kg}^{-1}\right.$ soil $)$} & 23.11 & Available - Zn(ppm) & 1.01 \\
\hline
\end{tabular}

\section{RESULTS AND DISCUSSION}

Data (Table 2) showed that salt stress $\left(\mathrm{EC}=4,8\right.$ and $\left.10 \mathrm{dSm}^{-1}\right)$ significantly $(p \leq 0.05)$ reduced the shoot fresh and dry weights as well as water content compared with non-saline conditions. These results are partially agreed with those obtained by (Shaddad et al., 2005; Rajpar et al., 2006; Tammam et al., 2008; Ahmadi et al., 2009, Addai and Abdul-Kareem, 2010; Mohammed, 2013) on wheat. Reduction in water content of seedlings grown in saline soils might have resulted internal water deficit to plants, which in turn, reduced the growth of shoots and roots. The reduction of most biomass changes of wheat by the salinity levels can be interpreted that the high concentration of $\mathrm{NaCl}$ causes negative effect on ionic balance and reduction of the content of $\mathrm{K}$ in the flag leaf sap led to stomatal closure subsequently reducing $\mathrm{CO}_{2}$ uptake and limiting photosynthesis and water content of plant decreases and plant lose turgor causing growth inhibition (Grewal et al., 2006). Fresh and shoot dry weight and water content percent of different cultivars differed significantly due to the mean effect of salinity levels (Table 3). The highest fresh and shoot dry weight was recorded in Abo-Graib followed by Sham 4 in which both significantly higher as compared to Rizgary and Semeto. A significant variation was obtained in percent water content of four selected wheat cultivars due to the mean effect of salinity levels. The highest percent water content was found in Sham 4 followed by Abo-Graib both were significantly higher than those of Rizgary and Semeto. The reduction in shoot biomass due to salt stress was more pronounced in 
Rizgary and Semeto than in Abo-Graib and Sham 4. In other means salt stress had a significant inhibitory effect on fresh and dry weight of shoots in Rizgary and Semeto, whears there was no significant variation among Rizgary and Semeto cultivars as well as among Abo-Graib and Sham 4 cultivars, hence according to Munns (2002) can be this two cultivar demonstrates sensitive tolerant to salinity with respect to others Abo-Graib and Sham 4 moderate to salt tolerant cultivars. These results are similar to those reported by (Shaddad et al., 2005; Saboora and Kiarostami, 2006; Goudarzi and Pakniyat, 2008; Tammam et al., 2008; Ahmadi et al., 2009) on different wheat cultivars. Addai and Abdul-Kareem (2010) showed significant differences among the three genotypes in all growth characters studied. 3.37 Maxback was superior compare to the others; genotypes differ in their salt tolerance ability, 3.37 Maxback and ACTED were more tolerant at compare to 3.41 Abu- Grab -3. Akbarimoghaddam et al., (2011) observed that increasing $\mathrm{NaCl}$ concentrations adversely affected shoot dry weight in studied each wheat cultivar; shoot dry weight fluctuated by varying $\mathrm{NaCl}$ concentrations. The lowest value found in Chamran cultivar and the higher value found in Sorkhtokhm and Kavir cultivars, maximum water uptake was recorded in Hamoon and Kavir cultivars and lowest was obtained with Hirmand and Sorkhtokhm. Mohammed (2013) reported a significant decrease in water uptake, shoot length and plant dry weight with the increasing of salinity level. Dor-29 cultivar showed the highest values in all characters.

Data presented in Table (4) shows significant decrease in Ntot, P, K, Mg and Ca content as well as $\mathrm{Fe}$ and $\mathrm{Cu}$ in shoots of wheat plants as a result of irrigation with saline water compared to tap water irrigation. Salinity level caused significant increases in the rate of $\mathrm{Na}, \mathrm{Cl}, \mathrm{Mn}$ and $\mathrm{Zn}$ in shoots of wheat plants as compared to control. These results are confirmed those obtained by Murat et al., (2007) who reported that application of $\mathrm{NaCl}$ caused decreases in $\mathrm{N}, \mathrm{K}, \mathrm{Fe}$ and $\mathrm{Cu}$ concentrations. Hirpara et al., (2005) on Butea monosperma seedlings when grown under salinity $\mathrm{NaCl}$ at $0.3,1.9,3.9,6.2,8.2,10.2,12.2$ and $13.8 \mathrm{dSm}^{-1}$. They found that $\mathrm{K}, \mathrm{Ntot}, \mathrm{Ca}, \mathrm{Mg}, \mathrm{Fe}$, and $\mathrm{K} / \mathrm{Na}$ exhibited significant decreases in shoots while there were significant increases in the concentration of $\mathrm{Na}, \mathrm{Cl}, \mathrm{Zn}, \mathrm{Cu}$ and $\mathrm{Mn}$ and accumulation of $\mathrm{Mn}$ has been recorded by ( $\mathrm{Hu}$ et al., 2000) in wheat. Solutions of $\mathrm{NaCl}\left(0,2,4,8\right.$, and $\left.10 \mathrm{dSm}^{-1}\right)$ was examined by Rajpar et al., (2006), they showed that the $\mathrm{Na}$ and $\mathrm{Cl}$ content was increased and that of $\mathrm{K}$ decreased which led to lower down the $\mathrm{K} / \mathrm{Na}$ ratio of the flag leaf sap in wheat (cv. Inqlab). Sodium content increased significantly in root, shoot and spikes of wheat $\mathrm{cv}$. Banysoif 1 grown in clay soil and irrigated by different saline waters $(0,60,120,180,240$ and $320 \mathrm{mM} \mathrm{NaCl})$. In general, salinity reduces $\mathrm{N}$ accumulation in plants; this is due to the fact that an increase in chloride uptake and accumulation is mostly accompanied by a decrease in shoot nitrate concentration and the uptake of Ca from the soil solution may decrease because of ion interactions, precipitation and increases in ionic strength that reduce the activity of $\mathrm{Ca}$ (Garg and Gupta, 1997). The low P-uptake by plants under the conditions of saline soil, in particular, resulted in the low growth obtained under such conditions (Turan et al., 2010). The observed decrease in K content might be related to the competition between the uptake of cations $\mathrm{Na}$ and $\mathrm{K}$. Such competition might be due to the existence of general carrier for their absorption by the roots (De- Lacerda et al., 2003). Hu and Schmidhalter (2001) also suggested that ions $\mathrm{Na}$ or $\mathrm{Cl}$ in high concentration in the external solution are taken up at high rates, which may lead to their excessive accumulation in the tissue. These ions may inhibit the uptake of other ions into the root and their transport to the shoot through the xylem, finally leading to a deficiency in the tissue. Flowers et al., (1977) reported that high $\mathrm{K}$ at higher salinity level is a good selection criterion for salt tolerance. The selective uptake of $\mathrm{K}$ as opposed to $\mathrm{Na}$ is considered to be one of the important physiological mechanisms contributing to salt tolerance in many plant species (Dashti et al., 2009). Under salt stress, plants maintain high concentrations of $\mathrm{K}$ and low concentrations of $\mathrm{Na}$ in the cytosol. There is a negative relationship between $\mathrm{Na}$ and $\mathrm{K}$ concentration in roots and leaves of many plants (Goudarzi and Pakniyat, 2008). Significantly higher concentrations of $\mathrm{Na}$ in plants in relation to more tolerance might explain the differences found between the responses, whether due to the toxic effect that the ion can produce. The data 
have shown that $\mathrm{K}$ uptake in the aerial part of the plant was significantly reduced with increased salinity in all cultivars.

Rate of shoot mineral content was varied considerably among the four wheat cultivars. The concentration of Ntot, $\mathrm{P}, \mathrm{K}, \mathrm{Ca}, \mathrm{Mg}, \mathrm{Na}, \mathrm{Cl}$ and $\mathrm{Zn}$ showed that there were significant differences $(p>0.05)$ among the cultivars. The highest concentration of $\mathrm{Ntot}, \mathrm{P}, \mathrm{K}, \mathrm{Ca}$ and $\mathrm{Mg}$ were found in Abo-Graib and Sham 4 and the lowest concentration in Semeto and Rizgary, whereas the highest concentration of $\mathrm{Na}, \mathrm{Cl}$ and $\mathrm{Zn}$ were found in Semeto and Rizgary and the lowest in Abo-Graib and Sham 4 (Table 5). However, non-significant differences were noticed between Semeto and Rizgary cultivars as well as between Abo-Graib and Sham 4 with regarding to all of the nutrient content. Both Abo-Graib and Sham 4 cultivar showed low Na concentrations and high $\mathrm{K}$ concentrations in their shoots, while the opposite was true with Semeto and Rizgary. Indeed, Abo-Graib and Sham 4 cultivar showed significant higher K/Na than Semeto and Rizgary (Table 5). A significant decrease in $\mathrm{K} / \mathrm{Na}$ indicates that $\mathrm{Na}$ was transferred to these tissues in greater proportion than $\mathrm{K}$. The increasing salinity stress decreased $\mathrm{K}$ and $\mathrm{K} / \mathrm{Na}$ ratio and increased $\mathrm{Na}$ in both genotypes of wheat and maize under two salinity levels, the higher amounts of $\mathrm{K}$ and $\mathrm{K} / \mathrm{Na}$ ratios in wheat compared to maize resulted in better ion homeostasis in wheat that caused this species to have a higher tolerance than maize (Ahmadi et al., 2009). Cuin et al., (2003) recorded that high $\mathrm{K} / \mathrm{Na}$ ratio is more important for many species than simply maintaining a low concentration of $\mathrm{Na}$, which makes sense given that much of the basis for Na toxicity is due to competition with $\mathrm{K}$ for $\mathrm{K}$ binding sites. Wyn Jones and Gorham (1986) suggested a minimum value of 1 for $\mathrm{K} / \mathrm{Na}$ ratio for normal growth of plants subjected to saline conditions. Maintenance of higher $\mathrm{K} / \mathrm{Na}$ ratios in salt tolerant lines may have been attributable to $\mathrm{K} / \mathrm{Na}$ exchange across the plasmalemma of root cortex cells and selective uptake of K (Dashti et al., 2009). The higher K/Na ratio in salt tolerant accessions may be one of reasons for their superior growth under saline conditions (Ashraf and Ahmad, 2000). Thus the difference in salt tolerance among the four wheat cultivars might be closely related to its ability to enhance $\mathrm{K} / \mathrm{Na}$ discrimination traits which enhanced the machinery of water flow. This was supported by the relative highest water content in shoots. In sever salinity plant tissues are able to maintain their water content much, for more tolerance to dehydration (Flowers et al., 1977). It is well established that the genotypes of plants vary widely in their ability to metabolize micronutrients efficiently and also, different varieties of the same species may differ in uptake efficiency of micronutrients as well (Marschner, 1995). Azooz (2004) observed differences in tolerance to chloride ions at high salinity levels among sorghum cultivars. Thus, the composition of macroelements and microelements alters greatly under varying levels of salinity and depends on plant species. It is well known that the micronutrients are generally less affected by salt stress than macronutrients (Iqbal et al., 2006). Nevertheless, plant species and their genotypes differ genetically in their ability to adapt to salt stress environment (Shahzad et al., 2012). Yousufinia et al., (2013) found that ion content of barley cultivars changed in salinity conditions and significant differences were observed between barley cultivars for various salt tolerance-associated traits under salinity stress.

Finally, the results shows that Abo-Graib and Sham 4 cultivars are moderately salt-tolerant compare to the other sensitive salt tolerant Rizgary and Semeto cultivars.

Table 2: Effect of salinity treatment on fresh weight, dry weight and water content of shoot of different wheat cultivars

\begin{tabular}{|c|c|c|c|}
\hline $\begin{array}{c}\text { Salinity } \\
\left(\mathbf{d S m}^{-\mathbf{1}}\right)\end{array}$ & $\begin{array}{c}\text { Shoot fresh weight } \\
\left(\mathbf{g ~ p l a n t}^{-\mathbf{1}}\right)\end{array}$ & $\begin{array}{c}\text { Shoot dry weight } \\
\left(\mathbf{g ~ p l a n t}^{-1}\right)\end{array}$ & Water content $\mathbf{~ \% ) ~}$ \\
\hline $\mathbf{0}$ & 13.01 & 7.58 & 71.63 \\
\hline $\mathbf{4}$ & 10.16 & 6.27 & 62.04 \\
\hline $\mathbf{8}$ & 7.80 & 5.01 & 55.68 \\
\hline $\mathbf{1 2}$ & 5.76 & 3.83 & 50.39 \\
\hline L.S.D $(\mathbf{0 . 0 5})$ & 2.77 & 1.21 & 8.03 \\
\hline
\end{tabular}


Table 3: Fresh weight, dry weight and water content of shoot of wheat cultivars grown under different salinity levels in the irrigation water.

\begin{tabular}{|c|c|c|c|}
\hline Cultivars & $\begin{array}{c}\text { Shoot fresh weight } \\
\left(\text { g plant }^{-1}\right)\end{array}$ & $\begin{array}{c}\text { Shoot dry weight } \\
\left(\text { g plant }^{-1}\right)\end{array}$ & Water content $(\%)$ \\
\hline Semeto & 7.32 & 4.87 & 50.30 \\
\hline Abo-Graib & 11.68 & 6.93 & 68.54 \\
\hline Sham-4 & 11.04 & 6.42 & 71.96 \\
\hline Rizgary & 6.69 & 4.47 & 49.66 \\
\hline L.S.D $(\mathbf{0 . 0 5})$ & 2.77 & 1.21 & 8.03 \\
\hline
\end{tabular}

Table 4: Nutrients content in wheat shoots as affected by different salinity levels in the irrigation water.

\begin{tabular}{|c|c|c|c|c|c|c|c|c|c|c|c|}
\hline $\begin{array}{l}\text { Salinity } \\
\left(\mathbf{d S m}^{-1}\right)\end{array}$ & \multicolumn{9}{|c|}{ Macronutrients $\left(\mathbf{m g ~ g}^{-1}\right.$ shoot $)$} & \multicolumn{3}{|c|}{ Micronutrients $\left(\boldsymbol{\mu g} \mathbf{~ g}^{-1}\right.$ shoot $)$} \\
\hline & $\mathbf{N}$ & $\mathbf{P}$ & $\mathbf{K}$ & $\mathbf{C a}$ & $\mathbf{M g}$ & $\mathbf{N a}$ & $\mathbf{C l}$ & $\mathbf{F e}$ & $\mathbf{M n}$ & $\mathbf{C u}$ & $\mathbf{Z n}$ \\
\hline $\mathbf{0}$ & 31.31 & 5.84 & 37.22 & 25.50 & 9.14 & 21.91 & 35.06 & 504 & 54.24 & 16.50 & 7.35 \\
\hline $\mathbf{4}$ & 29.45 & 4.47 & 34.83 & 26.04 & 8.71 & 32.39 & 40.78 & 468 & 57.18 & 14.84 & 7.57 \\
\hline $\mathbf{8}$ & 21.62 & 2.73 & 26.27 & 14.76 & 6.55 & 50.89 & 74.26 & 272 & 64.75 & 14.16 & 9.02 \\
\hline $\mathbf{1 2}$ & 12.41 & 1.05 & 19.14 & 14.25 & 5.37 & 82.67 & 112.54 & 159 & 70.25 & 12.25 & 12.60 \\
\hline L.S.D (0.05) & 5.90 & 1.21 & 7.23 & 6.11 & 1.02 & 9.44 & 27.57 & 078 & 8.25 & 2.10 & 1.28 \\
\hline
\end{tabular}

Table 5: Nutrients content and $\mathrm{K} / \mathrm{Na}$ ratio in wheat shoots as affected by different salinity levels in the irrigation water.

\begin{tabular}{|c|c|c|c|c|c|c|c|c|c|c|c|c|}
\hline \multirow[t]{2}{*}{ Cultivars } & \multicolumn{7}{|c|}{ Macronutrients (mg g ${ }^{-1}$ shoot) } & \multirow{2}{*}{$\begin{array}{l}\text { K/Na } \\
\text { ratio }\end{array}$} & \multicolumn{4}{|c|}{ Micronutrients $\left(\mu \mathrm{g} \mathrm{g}^{-1}\right.$ shoot $)$} \\
\hline & $\mathbf{N}$ & $\mathbf{P}$ & $\mathbf{K}$ & $\mathbf{C a}$ & Mg & $\mathbf{N a}$ & Cl & & $\mathbf{F e}$ & Mn & $\mathbf{C u}$ & $\mathbf{Z n}$ \\
\hline Semeto & 20.05 & 2.92 & 24.41 & 16.83 & 6.05 & 58.10 & 79.35 & 0.42 & 333 & 59.95 & 15.01 & 9.93 \\
\hline Abo-Graib & 27.40 & 4.20 & 37.00 & 23.11 & 8.73 & 34.99 & 48.01 & 1.05 & 368 & 57.29 & 14.63 & 7.85 \\
\hline Sham-4 & 25.91 & 4.41 & 33.80 & 25.43 & 9.01 & 30.15 & 45.83 & 1.12 & 380 & 64.06 & 14.34 & 8.31 \\
\hline Rizgary & 19.41 & 2.56 & 22.25 & 15.18 & 5.98 & 64.64 & 89.48 & 0.34 & 320 & 65.12 & 13.77 & 10.41 \\
\hline $\begin{array}{l}\text { L.S.D } \\
(0.05)\end{array}$ & 5.90 & 1.21 & 7.23 & 6.11 & 1.02 & 9.44 & 27.57 & 0.26 & n.s. & n.s. & n.s. & 1.28 \\
\hline
\end{tabular}

\section{CONCLUSIONS}

Salinity disturb the mineral-nutrient relations in plants through their effects on nutrient availability, transport, partitioning in plants and induces ion deficiency or imbalance due to the competition of nutrients such as $\mathrm{K}, \mathrm{Ca}$, and $\mathrm{NO}^{-3}$ with the toxic ions $\mathrm{Na}$ and $\mathrm{Cl}$. Mineral nutrients play a vital role in determining plant resistance to salinity. $\mathrm{K}$ is equally important to maintain the turgor pressure of the plant under either stress. High K: Na ratios will also improve the resistance of the plant to salinity. The competition between $\mathrm{Cl}$ and $\mathrm{NO}^{-3}$ under saline conditions means that the form of $\mathrm{N}$ plays a critical role in determining the growth of salinized plants. Compared to Ntot, $\mathrm{P}$, $\mathrm{K}$, and $\mathrm{Ca}$, however, micronutrients might be less important with respect to plant resistance to salinity.

\section{REFERENCES}

Addai, Z.R.; Abdul-Kareem, N.O.(2010). Effect of irrigation water salinity on seed germination and plant growth of three genetic structures for bread wheat (Triticum aestivum. L.). Thi- Qar Sci. J., 2(1), 1-8.

Ahmadi, A.; Emam, Y.; Pessarakli, M.(2009). Response of various cultivars of wheat and maize to salinity stress. J. Food Agri. Environ., 7, 123 - 128.

Akbarimoghaddam, H.; Galavi, M.; Ghanbari, A.; Panjehkeh, N. (2011). Salinity effects on seed germination and seedling growth of bread wheat cultivars. Trakia J. Sci.,9(1), 43-50. 
Ashraf, M.; Ahmad, S. (2000). Influence of sodium chloride on ion accumulation, yield components and fiber characteristics in salt-tolerant and salt-sensitive lines of cotton (Gossypium hirsutum L.). Field Crops Res., 66, 115-127.

Azooz, M.M. (2004). Proteins, sugars and ion leakage as a selection criterion for the salt tolerance of three sorghum cultivars at seedling stage grow under $\mathrm{NaCl}$ and nicotinamide. Int. J. Agri. Biol., 6(1), 27-35.

Bohnert, H.J. (2007). "Abiotic Stress". John Wiley and Sons, Ltd.

Chinnusamy, V.; Jagendorf, A.; Zhu, J.K.(2005). Understanding and improving salt tolerance in plants. Crop Sci., 45, 437-448.

Cuin,T.A.; Miller, A.J.; Laurie, S.A.; Leigh, R.A.(2003). Potassium activities in cell compartments of salt grown barley leaves. J. Exp. Bot., 54, 657-661.

Dashti, A.; Khan, A.A.; Collins, J. C. (2009). Effect of salinity on growth, ionic relations and solute content of Sorghum bicolor (L.) Moench. J. Plant Nutr. (Accepted).

De- Lacerda, C.F.; Cambraia, J.;Oliva, M.A.;Ruiz, H.A.; Prisco, J.T.(2003). Solute accumulation and distribution during shoot and leaf development in two genotypes under salt stress. Envinm. Exp. Bot. 49,107-120.

Flowers, T.J.; Troke, P.F.; Yeo, A.R. (1977). The Mechanism of salt tolerance in halophytes. Annu. Rev. Plant Physiol., 28, 89-121.

Garg, B.K.; Gupta, I.C. (1997). "Saline Wastelands Environment and Plant Growth". Jodhpur, Scientific Publishers.

Goudarzi, M.; Pakniyat, H. (2008). Evaluation of wheat cultivars under salinity stress based on some agronomic and physiological traits. J. Agri. Soc. Sci., 1, 35-38.

Grewal, H.S.; Norrish, S.; Cornish, P. (2006). Subsoil salts affect root function; shoot growth and ionic balance of wheat plants. UWS, Hawksbury Campus, NSW, 2753.

Hanlon, E.A. (1992). "Determination of Potassium, Calcium and Magnesium in Plant by Atomic Absorption Techniques".C.O Plank (E.d).pp33-36.

Hirpara, K.; Ramoliya, D.P.J.; Patel, A.D.; Pandey, A.N.(2005).Effect of Stalinization of soil on growth and macro- and micro-nutrient accumulation in seedlings of Butea monosperma (Fabaceae). Anales de Biologia, 27, 3-14.

$\mathrm{Hu}, \mathrm{Y}$; Schmidhalter, U. (2001). Effects of salinity and macronutrient levels on micronutrients in wheat. J. Plant Nutr., 24, 273-281.

Hu, Y.; Tucher, V.S.; Schmidhalter, U. (2000). Spatial distributions and net deposition rates of Fe, $\mathrm{Mn}$ and $\mathrm{Zn}$ in the elongating leaves of wheat under saline soil conditions. Aust. J. Plant Physiol., 27, 53-59.

Iqbal, N.; Ashraf, M.Y.; Farrukh, J.; Vicente, M.; Kafeel, A. (2006). Nitrate reduction and nutrient accumulation in wheat (Triticum aestivum L.) grown in soil salinization with four different salts. J. Plant Nutr., 29, 409-421.

Levesque, R. (2007). "SPSS Programming and Data Management": A guide for SPSS and SAS users, $4^{\text {th }}$ edn, SPSS Inc., Chicago.

Marschner, H. (1995). "Mineral Nutrition of Higher Plants". $2^{\text {nd }}$ edn. Academic Press, London.

Mohammed, L.Sh. (2013). Comparison of salt tolerance among some bread and durum wheat cultivars in germination and seedling development stages. Tikrit Univ. J. Agri. Sci., 13(1), 135-142.

Muhling, K.H.; Lauchli, A. (2003). Interaction of $\mathrm{NaCl}$ and $\mathrm{Cd}$ stress on compartmentation pattern of cations, antioxidant enzymes and proteins in leaves of two wheat genotypes differing in salt tolerance. Plant Soil, 253,219-231.

Munns, R. (2002). Comparative physiology of salt and water stress. Plant Cell Environ. 25,239-250

Murat, A.T.; Katkat, V.; Suleyman, T. (2007). Variations in proline, chlorophyll and mineral elements contents of wheat plants grown under salinity stress. J. Agronomy 6(1), 137- 141. 
Pandey, O.P.; Bajpai, D.N.; Giri, S. (2000). "Practical Chemistry". S.Chand Company LTD., pp.117-120.

Poustini, K.; Siosemardeh, A.(2004). Ion distribution in wheat cultivars in response to salinity stress. Field Crops Res., 85:125- 33.

Rajpar, I.; Khanif, Y.M.; Suthar, J.K. (2006). Effect of $\mathrm{NaCl}$ on the growth and yield of Inqlab (Triticum aestivum L.) variety. American. J. Plant Physiol., 1(1), 34-40.

Rana, G.; Katerji, N. (2000). Measurement and estimation of actual evapotranspiration in the field under Mediterranean climate: a review. European J. Agro., 13 (2-3),25-153.

Rhoades, J.D.; Kandiah, A.; Mashali, A.M. (1992). The Use of saline waters for crop production. FAO Irr. and Drain. Paper No: 48, pp. 1-133, Rome.

Russel, J.C.; Kadry, L.; Hanna, A.B.(1965). Sodic soils in Iraq. Agrokomia ES Talajtan.Tom 14(Suppl.), 91-97.

Ryan, J.; Estefon, G.; Rashid, A. (2001). Soil and Plant Analysis Laboratory Manual, $2^{\text {nd }}$ edn. National Agriculture Research Center (NARC) Islamabad, Pakistan. sabdariffa L. seedlings. Bull. Fac. Sci., 31(2-D), 395-303.

Saboora, A.; Kiarostami, K. (2006). Salinity tolerance of wheat genotype at germination and early seedling growth. Pakistan J. bio. Sci., 9(11), 2009-2021.

Shaddad, M.A.; Ismail, A.M.; Azooz, M.M.; Abdel- Latef, A. (2005). Effect of salt stress on growth and some related metabolites of three wheat cultivars. Assuit Univ. J. Bot., 34, 477-491.

Shahzad, A.; Ahmad, M.; Iqbal, M.; Ahmed, I.; Ali, G.M. (2012). Evaluation of wheat landrace genotypes for salinity tolerance at vegetative stage by using morphological and molecular markers. Genetics and Molecular Research. 11(1), 679-692.

Tammam, A.A.; Abou Alhamd, M.F.; Hemeda, M.M.(2008). Study of salt tolerance in wheat (Triticum aestium L.) cultivar Banysoif 1. Australian J. Crop Sci., 1(3),115-125.

Temminghoff, E.J.M.; Houba, E.V.J.G. (2004). "Plant Analysis Procedures" $2^{\text {nd }}$ edn. Kluwer Academic Publishers, London, pp.157-163.

Tester, M.; Davenport, R. (2003). Na tolerance and Na transport in higher plants. Ann. Bot., 91, 503-527.

Turan, M.A.; Elkarim, A.H.A.; Taban, N.; Taban, S. (2010). Effect of salt stress on growth and ion distribution and accumulation in shoot and root of maize plant. Afr. J. Agric. Res., 5(7), 584588.

Wyn Jones, R.G.; Gorham, J. (1986). The potential for enhancing the salt tolerance of wheat and other important crop plants. Outlook on Agric., 15, 33-39.

Yousufinia, M.; Alireza, G.;Omid, S.; Asadollah, A.(2013). The effect of $\mathrm{NaCl}$ on the growth and $\mathrm{Na}+$ and $\mathrm{K}+$ content of barley (Hordeum vulgare, L.) cultivars. Annals of Biological Research, 4 (1),80-85. 